\title{
Fasting habits, sleep duration, energy availability, and chronic energy deficiency (CED) risk in female students
}

\author{
Faradila, U.N., Wijayanti, H.S., Tsani, A.F.A., Widyastuti, N., Fitranti, D.Y. and \\ *Dieny, F.F.
}

Department of Nutrition Science, Faculty of Medicine, Universitas Diponegoro, Indonesia

\author{
Article history: \\ Received: 31 January 2020 \\ Received in revised form: 26 \\ March 2020 \\ Accepted: 19 April 2020 \\ Available Online: 30 May \\ 2020
}

\section{Keywords:}

Fasting habits,

Energy availability,

Sleep duration,

CED risk,

Female students

\section{DOI:}

https://doi.org/10.26656/fr.2017.4(S3).S21

\begin{abstract}
Fasting habits that are not followed by a healthy balanced diet along with sleep deprivation may cause low energy availability which increases the risk of Chronic Energy Deficiency (CED). This study was aimed to describe and analyze the relationship between fasting habits, sleep duration, energy availability and CED risk in Female Students. This study was an observational study conducted in Kyai Galang Sewu Islamic Boarding School. The total subjects were 98 female students age 18-24 that were selected by simple random sampling method. CED risk data was assessed using mid-upper arm circumference (MUAC). Fasting habits data was obtained from a questionnaire consisting related to type and duration of fasting, total fasting days and frequency of meals during fasting. Energy availability data was obtained by subtracting energy expenditure from energy intake divided by fat-free mass. Sleep duration data were obtained using the Sleep Timing Questionnaire. Univariate analysis was used to describe each of the variables. Bivariate analysis was performed using Rank Spearman test. Subjects who had CED risk was $44.9 \%$. Subjects that practised fasting regularly was $76.5 \%$, in which $51 \%$ of them fast on Monday and Thursday. A total of $49.3 \%$ subject often missed early breakfast. All subjects had low sleep duration and low energy availability. There was no relationship between the duration of fasting habits, total days of fasting, and sleep duration with energy availability $(\mathrm{p}>0.05)$. However, there was a positive relationship between meal frequency during fasting and energy availability $(\mathrm{r}=0.36, \mathrm{p}<0.001)$ and a positive relationship between energy availability and MUAC $(r=0.39, p<0.001)$. Low energy availability was related to CED risk, while energy availability was influenced by the frequency of meals during fasting.
\end{abstract}

\section{Introduction}

The number of reproductive age women in Indonesia is the largest number among Southeast Asia countries, 65 million (Mujiati et al., 2013). A large number of reproductive age women in Indonesia emphasize the importance of good nutritional status, especially in dealing with pregnancy. However, nutritional problems in reproductive age women in Indonesia are still relatively high.

One of the nutrition problems that usually occur in reproductive age women is Chronic Energy Deficiency (CED). CED is a condition where a person suffers from an imbalance of nutrient intake (energy and protein) that lasts for a long time (Muliawati, 2013). CED on reproductive-age women has some negative impacts, one of them was giving birth to low birth weight infant
(Ariyani et al., 2012). Therefore, it is important to women at this age to prepare physically, and mentally to become a healthier mother.

The prevalence of CED risk in non-pregnant reproductive-age women in Indonesia based on the MidUpper Arm Circumference (MUAC) indicator was $14.5 \%$ in Indonesia (Kementrian kesehatan RI, 2018). The prevalence of CED risk in reproductive age women increased from 2007 to 2018 . It increased from 30,9\% to $36,3 \%$ among women aged $15-19$ years old, and increase from $18,2 \%$ to $23,3 \%$ among women aged $20-24$ years old (Kementrian kesehatan RI, 2018).

One group of reproductive age women in Indonesia which is susceptible to experience nutritional problems is female students in Islamic Boarding School (Santriwati). A study conducted at Al-Hidayah Islamic Boarding 
School in Grobogan, Indonesia showed results that $51.1 \%$ of students had underweight nutritional status caused by inadequate nutritional intake (Inayati, 2009). Other studies conducted at Salafiyah Kauman Pemalang Islamic Boarding School, Indonesia also showed results that $38 \%$ female students had poor nutritional status (Hidayah et al., 2016). Furthermore, a study about food service system management at the Hubulo Islamic Boarding School in Gorontalo, Indonesia showed that the nutritional value of the food provided by school only met $76 \%$ of the total needs (Taqhi et al., 2014).

Low energy and nutrient reserves can cause CED in reproductive age women since adolescence and continue during pregnancy and breastfeeding (Ariyani, 2012). Energy availability represents the energy remaining for other metabolic processes to ensure proper physiological functions. Energy availability is the difference between energy intake and energy expended during exercise (relative to fat-free mass) (Ong and Brownlee, 2017). The value of energy availability $30 \mathrm{kcal} / \mathrm{kg} \mathrm{FFM} /$ day is the threshold for the availability of energy needed for physiological functions (Papageorgiou et al., 2018). Low energy availability usually occurs in athletes, where athletes have a lot of energy expenditure and are often not followed by adequate intake due to intake restrictions to maintain body weight (Sygo et al., 2018).

Low energy availability is also possible to occur in female students because of the habits carried out by female students, including the high activity as students because they have to divide their time between formal education and religious activities in Islamic boarding schools, sleep deprivation, and fasting habits which is not followed by a healthy balanced diet. Female students who are still pursuing formal education must be able to divide their time between religious activities and formal education activities, thus they have a lot of activities. The greater the physical activity carried out, the greater the energy expenditure of a person (Westerterp, 2013).

The activities of female students who live in Islamic boarding schools are dense thus students often have less time to sleep. Research on energy expenditure during sleep showed that energy expenditure significantly increased by $\sim 32 \%$ when a person experienced sleep deprivation at night and significantly decreased $\sim 4 \%$ during sleep recovery (Jung et al., 2011). Other study showed that a low duration of sleep (4-5 hours a night) caused an increased in energy expenditure of $92 \mathrm{kcal}$ or $\sim 5 \%$ (Shechter et al. , 2013).

Another habit that is often practised by female students is sunnah fasting habits. Fasting can change the intake of nutrients due to the changes in diet. Fasting can increase insulin sensitivity, improve cognitive function, prevent cancer, and improve cardiovascular function if it is followed by a good diet (Golbidi et al., 2017). However, a study conducted at the Al-Itqon Bugen Islamic Boarding School in Semarang, Indonesia showed that female students who practised Monday and Thursday fasting habits consumed food that did not meet nutritional needs. The results showed that female students who practised Monday and Thursday fasting only had $77,87 \%$ of energy adequacy (Kustiyanti and Kartasurya, 2017).

There was no study conducted about energy availability among female students, how their habits may affect their energy availability, and how their energy availability may affect on CED risk. This study aimed to describe and analyzed the relationship between fasting habits, sleep duration, and energy availability in female students as well as the relationship between energy availability and CED risk.

\section{Materials and methods}

\subsection{Design, location and time}

This study was an observational study with a crosssectional design and this research conducted in Kyai Galang Sewu Islamic Boarding School Semarang, Indonesia in April 2019. The entire study was approved by the Health Research Ethics Committee of the Faculty of Medicine, Universitas Diponegoro/Dr. Kariadi Central General Hospital Number 162/EC/KEPK/FK-UNDIP/V/ 2019.

\subsection{Samplings}

The total number of subjects was 98 female students age 18-24 selected by a simple random sampling method. Inclusion criteria applied were female students who were active in the Kyai Galang Sewu Islamic Boarding School, did not have infectious diseases (typhoid fever, chronic diarrhea, tuberculosis, hepatitis, malaria, dengue fever), did not consumption supplements or drugs that can affect body composition, and agreed to be subject for this study.

\subsection{Data collected}

The independent variables in this study were fasting habits, sleep duration, and energy availability. The dependent variable was the CED risk. Data collected were subject characteristics data, fasting habits, sleep duration, energy availability, height, weight, fat-free mass, and mid-upper arm circumference.

The fasting habits data was obtained from a questionnaire to assess type and duration of fasting habits, total fasting days and frequency of meals during fasting. The type of fasting was kind of fasting which 
was routinely performed by female students. The duration of fasting habits was the period length from female students started sunnah fasting up to the time when the data was collected. Total fasting days was the number of days female students practised sunnah fasting in a month. The frequency of meals during fasting was the number of main meals on a fasting day.

Energy availability data was obtained by subtracting energy expenditure from energy intake divided by fat free mass (FFM). Subjects were categorized have low energy availability if less than $30 \mathrm{kcal} / \mathrm{kg} \mathrm{FFM} /$ day, normal if $30 \mathrm{kcal} / \mathrm{kg} \mathrm{FFM} /$ day to $45 \mathrm{kcal} / \mathrm{kg} \mathrm{FFM} /$ day, and high if $>45 \mathrm{kcal} / \mathrm{kg}$ FFM/day (Márquez and Molinero, 2013). Energy intake data were obtained from 6 x 24 hours of food recalls and analyzed using Nutrisurvey 2007 software. Twenty-four hours food recalls was performed on four weekdays and two weekends to those who practised ngrowot fasting, naun fasting, or did not practice fasting, on three fasting days and three non-fasting days to those tho practised Duad fasting, and two fasting days and four non-fasting days to those who practised Monday and Thursday fasting. Energy expenditure was calculated using the formula 3.5 x Body Weight x 5/1000 x Multiples of Basal Energy Metabolism (EMB) $x$ time (Setyarsih et al., 2017). The total time of energy expenditure was derived from 24hour physical activity obtained using 6x24-hour physical activity record questionnaire, which was collected simultaneously with the $6 \times 24$ hour-food recalls data collection. Fat-free mass data were obtained from measurements of body composition using BIA Tanita DC 360.

Sleep duration data were obtained using the Sleep Timing Questionnaire (STQ) (Ramadhaniah et al., 2014). The questionnaire contained questions related to sleep time in the last one month consisting of bedtime on weekdays and weekends. Subjects were categorized as having less sleep if the duration of sleep was less than 7 hours, enough if the duration of sleep was $\geq 7$ hours (Ramadhaniah et al., 2014). CED risk data was assessed using the Mid-Upper Arm Circumference (MUAC). Subjects were categorized as having CED risk if the value of MUAC was less than $23.5 \mathrm{~cm}$ (Kementrian kesehatan RI, 2018).

\subsection{Data analysis}

Normality data test was performed by the Kolmogorov-Smirnov test and univariate analysis was used to describe each of the variables. Bivariate analysis was performed using the Spearman Rank test.

\section{Results}

\subsection{The characteristics of subjects}

The median age of the subjects was 20 years and median mid-upper arm circumference (MUAC) of the subjects was $23.5 \mathrm{~cm}$. The median duration of fasting habit was 11 months, median total fasting days was 6 days, while the median frequency of meals during fasting was 1 time per day. The characteristics of subjects can also be seen in Table 1. Median energy intake was $1,028.5 \mathrm{kcal}$, median energy expenditure was $951.5 \mathrm{kcal}$, the median fat-free mass was $33.7 \mathrm{~kg}$, median energy availability was $1.85 \mathrm{kcal} / \mathrm{kg} \mathrm{FFM} /$ day. Median sleep duration of subjects was 4 hours per day. The categories fasting habit, sleep duration, energy availability and CED status presented in Table 2. As many as $76.5 \%$ of subjects had fasting habit. The most common type of fasting was Monday and Thursday fasting which is $51 \%$ $(\mathrm{n}=50)$ subjects. A much as $49.3 \%(\mathrm{n}=37)$ female students often missed early breakfast. All subject (100\%) had low energy availability and sleep duration. Table 3 describes that a total of $44.9 \%$ female students was at risk of CED. The type of fasting habits and CED risk. Subjects who did not practice fasting but experienced

Table 1. Characteristics of subjects

\begin{tabular}{lccc}
\hline \multicolumn{1}{c}{ Variable } & Median & Minimum & Maximum \\
\hline Age (years) & 20 & 18 & 24 \\
Weight (kg) & 46.7 & 32.9 & 67.5 \\
Height (cm) & 152.5 & 139 & 169.5 \\
MUAC (cm) & 23.5 & 19 & 30,5 \\
Fasting Habit & & & \\
$\quad$ Duration of Fasting Habit (month) & 11 & 0 & 147 \\
$\quad$ Total Fasting Days (day/month) & 6 & 0 & 30 \\
$\quad$ Frequency of Meals (time/day) & 1 & 0 & 2 \\
Energy Availability & 1.85 & 1 & 9.5 \\
$\quad$ Energy Intake (kcal) & 1028.5 & 815 & 1596 \\
$\quad$ Energy Expenditure (kcal) & 951.5 & 766 & 1285 \\
$\quad$ Fat Free Mass (kg) & 33.7 & 26.5 & 44.2 \\
Sleep Duration (hours/day) & 4 & 2 & 6.5 \\
\hline
\end{tabular}


CED risk were $30.4 \%$. Subjects who practised Monday and Thursday fasting and experienced CED risk was $44 \%$, while subjects who practised Daud Fasting and experienced CED risk was $57.1 \%$.

Table 2. Categories of fasting habit, sleep duration, energy availability and CED status

\begin{tabular}{lcc}
\hline Category & $\mathrm{n}$ & $\%$ \\
\hline Not Fasting & 23 & 23.5 \\
Fasting & & \\
$\quad$ Monday and Thursday Fasting & 50 & 51 \\
$\quad$ Daud Fasting & 14 & 14.3 \\
$\quad$ Ngrowot Fasting & 1 & 1 \\
$\quad$ Naun Fasting & 3 & 3.1 \\
$\quad$ Monday and Thursday and Ngrowot & 1 & 1 \\
$\quad$ Fasting & & \\
$\quad$ Monday and Thursday and Ayyamul & 6 & 6.1 \\
$\quad$ bidh Fastng & & \\
Early Breakfast Habit & & \\
$\quad$ Early Breakfast & 38 & 50.7 \\
$\quad$ Missed Early Breakfast & 37 & 49.3 \\
Energy Availability & & \\
$\quad$ Low & 98 & 100 \\
Sleep Duration & & \\
$\quad$ Low & 98 & 100 \\
CED status & & \\
$\quad$ CED Risk & & \\
$\quad$ Normal & 54 & 54.9 \\
\hline
\end{tabular}

Table 3. Type of fasting and CED risk

\begin{tabular}{lcccc}
\hline \multirow{2}{*}{\multicolumn{1}{c}{ Type of Fasting }} & \multicolumn{5}{c}{ CED Status } \\
\cline { 2 - 5 } & \multicolumn{3}{c}{ CED Risk } & \multicolumn{2}{c}{ Normal } \\
\cline { 2 - 5 } & $\mathrm{n}$ & $\%$ & $\mathrm{n}$ & $\%$ \\
\hline Not Fasting & 7 & 30.4 & 16 & 69.6 \\
$\begin{array}{l}\text { Monday and Thursday } \\
\text { Fasting }\end{array}$ & 22 & 44 & 28 & 56 \\
Daud Fasting & 8 & 57.1 & 6 & 42.9 \\
Ngrowot Fasting & 1 & 100 & 0 & 0 \\
Naun Fasting & 2 & 66.6 & 1 & 33.3 \\
$\begin{array}{l}\text { Monday and Thursday, } \\
\text { Ngrowot Fasting }\end{array}$ & 0 & 0 & 1 & 100 \\
$\begin{array}{l}\text { Monday and Thursday, } \\
\text { Ayyamul Bidh Fasting }\end{array}$ & 4 & 66.6 & 2 & 33.3
\end{tabular}

*Monday and Thursday Fasting is one type of fasting which is carried out on Monday and Thursday; Daud fasting is a type of sunnah fasting, where fasting is intermittent ie daily fasting a day is not; Naun fasting is a type of fasting that is practised for a full year except during menstruation and days that are prohibited from fasting; Ngrowot fasting is one of fasting which is carried out by not consuming rice as a basic necessity as usual and replacing it with other carbohydrate sources such as cassava, corn; Ayyamul bidh fasting is a fast that is carried out every mid-month $(13,14,15)$ of the Hijri based on the Qomariah calendar.
3.2 The relationship between fasting habits, sleep duration and energy availability

The relationship berween fasting habits, slep duration and energy availability can be seen in Table 4 . There was no relationship between duration of fasting, total days of fasting and energy availability $(\mathrm{p}=0.34 ; \mathrm{r}=$ -0.09 and $(\mathrm{p}=0.84 ; \mathrm{r}=0.02$ respectively). There was a relationship between the frequency of meals during fasting and energy availability $(p=0.001 ; r=0.385)$, in which the less frequency of meals, the lower the energy availability. There was no relationship between sleep duration and energy availability $(p=0.63 ; r=0.05)$.

Table 4. The relationship between fasting habits, sleep duration and energy availability

\begin{tabular}{lcc}
\hline \multicolumn{1}{c}{ Variable } & $\mathrm{r}$ & $\mathrm{p}^{\text {-value }}{ }^{\mathrm{a}}$ \\
\hline Fasting Habits & & \\
Duration of Fasting (month) & -0.09 & 0.34 \\
Total Days of Fasting (day/month) & 0.02 & 0.84 \\
Frequency of Meals (time/day) & 0.36 & $0.001^{*}$ \\
Sleep Duration (hours/day) & 0.05 & 0.63 \\
\hline
\end{tabular}

${ }^{a}$ Rank Spearman Test. *Significant $(p<0.05)$

\subsection{The relationship between energy availability and mid} -upper arm circumference (MUAC)

Table 5 describes that there was a relationship between energy availability and MUAC ( $p<0.001 ; r=$ 0.39 ), in which the lower energy availability, the lower the MUAC.

Table 5. The relationship between energy availability and (MUAC)

\begin{tabular}{lcc}
\hline Variable & r & p-value ${ }^{\mathrm{a}}$ \\
\hline Energy Availability $(\mathrm{kcal} / \mathrm{kg}$ FFM/day) & 0.39 & $<0.001 *$ \\
\hline${ }^{\mathrm{a}}$ Rank Spearman Test. ${ }^{*}$ Significant $(\mathrm{p}<0.05)$ & &
\end{tabular}

\section{Discussion}

Energy availability in female students was influenced by energy intake and energy expenditure. Energy intake was also influenced by many factors, included fasting habits. The fasting habit was one of the habits commonly practised by female students. Types of fasting carried out at Kyai Galang Sewu Islamic Boarding School were varied, including Monday and Thursday, Daud, Ngrowot, Naun, and Ayyamul Bidh fasting. Monday and Thursday fasting was the most widely practised among female students. The type of based on personal preference and was not based on regulation or from the Islamic Boarding School.

This study showed that the frequency of eating during fasting affected energy availability, the less frequency of main meals during fasting, the lower energy 
availability of energy. They who run sunnah fasting often missed early breakfast and only eat a meal a day, thus their food intakes tends to be less than their needs. This finding was supported by research conducted by A1Itqon Islamic Boarding School in Semarang in which students who practised Monday and Thursday fasting had lower energy adequacy compared to those who did not fast due to frequent missed early breakfas $t$ (Kustiyanti and Kartasurya, 2017). Low energy intake could cause low energy availability (Ong and Brownlee, 2017). Research at Roudlatul Hidayah Islamic Boarding School also showed that lack of eating frequency caused energy adequacy could not be fulfilled, thus increased risk of low nutritional status such as Chronic Energy Deficiency (CED). It was recommended to have an eating frequency as many as 3 times a day of main meals and 2 times a day of snacks (Khusniyati et al., 2016).

However, this study could not show that duration of fasting and the total days of fasting in a month affected the energy availability. Some subjects have fasting habit for a long time before entering the Islamic Boarding School. A total of $65.3 \%$ of them had routinely carried out fasting for more than one year. Their main reasons for fasting were to improve patience and increased gratitude to God. Most of the students who had practised fasting for a long time had the habit of eating 2 meals a day, included early breakfast (suhoor). Therefore, long duration of fasting did not affect the energy intake adequacy as long as the food intake or frequency of eating during fasting was sufficient. Research by Desy Kustiyanti stated that there was no difference in nutritional status between subjects who fast on Monday and Thursday with subjects who did not fast. Good nutritional status will be achieved if food intake during fasting remains good (Kustiyanti and Kartasurya, 2017).

Fasting habits that affected energy were only the frequency of meals during fasting. This finding proved that sunnah fasting was good to be carried out both frequently and in a long period if it was followed by a good diet. Fasting actually provides many benefits such as increasing insulin sensitivity, improving cognitive function, preventing cancer, and improving cardiovascular function if followed by a good diet (Golbidi et al., 2017).

In addition, energy availability could also be influenced by energy expenditure that was influenced by sleep duration. The sleep duration for subjects was all low sleep duration. This was because they have to divide their time between religious activities in Islamic boarding school and learning activities on campus. Religious activities finished at 11:00 pm, but after that, they still had to work on college assignments thus they had less sleep. However, the correlation test showed that there was no relationship between sleep duration and energy availability.

Based on existing theories, lack of sleep could increase a person's energy expenditure thereby reducing the value of energy availability if it was not balanced with adequate energy intake (Shechter et al., 2013; Melin et al., 2015). High energy expenditure could cause low energy availability. In this study, the lower sleep duration might increase energy expenditure since the subject who had low sleep duration on average had higher physical activity at night. The higher energy expenditure was due to multiple energy metabolism when sitting was higher than sleep. Therefore, the energy expenditure among subject who stayed up late was higher than students who slept early.

However, it turned out that subject who slept late tended to had early breakfast because they felt hungry when working on college assignments. Therefore, food intake was higher because they usually ate the meal before bedtime at around 1;00 to 2;00 a.m. Research in China showed that subjects who lack sleep had higher energy intake. Similarly, other studies by Marie-Pierre St -Onge, mentioned that subjects who had lower sleep duration experienced increase energy and fat intake (StOnge et al., 2011). Higher energy intake was influenced by a decrease in leptin levels resulting in an increase in hunger and appetite (Gong et al., 2018). However, research by Novziransyah and Daulay (2018) showed that sleep duration was not related to student nutritional status. This study showed that lack of sleep might increase energy expenditure, but in another way around, it also increased energy intake. Therefore, it might explain why this study could not show the relationship between sleep duration and energy availability

Energy availability is the amount of energy in the body that is used for all physiological functions after calculating energy intake and energy expenditure for physical activity (Márquez and Molinero, 2013). The lower energy availability in this study mainly due to the low energy intake because they often missed the early breakfast. The statistical tests showed that there was a relationship between MUAC and energy availability, in which the lower energy availability, the smaller MUAC. Energy availability represents energy reserves for metabolic processes so that they can carry out physiological functions properly. Low energy and nutrient reserve could increase the risk of CED (Ong and Brownlee, 2017). Loucks stated that the low value of energy availability could cause a person to lose muscle mass or fat mass in his body. If it lasted long, it could reduce the body ability to carry out its physiological 
functions properly (Holtzman and Ackerman, 2019). If there were continuous depletion of muscle mass and it was not accompanied with adequate food intakes, it would increase the risk of CED (Hadi et al., 2014).

A total of $44.8 \%$ of female students in this study had experienced CED risk. Subjects who did not practise a good diet were vulnerable to having a low nutritional status. Statistic analysis in this study showed that low energy intake had a significant correlation with the risk of CED. Therefore, it can be assumed that the energy intake was a component of energy availability risk in subjects. The measurement of energy status such as energy availability is an accurate and objective measurement and may reflect a compensation of CED compared to just using nutritional status measurement only (Williams et al.,2018).

\section{Conclusion}

A total of $44.9 \%$ of female students experienced the risk of CED. Subjects who had fasting habit was $76.5 \%$, in which the Monday and Thursday fasting was the most practised by subjects (51\%). All students had low sleep duration and low energy availability. There was a correlation between the frequency of meals during fasting and energy availability, but there was no relationship between duration of fasting, total days of fasting, sleep duration and energy availability. Energy availability was related to the risk of CED in subjects.

\section{Conflict of interest}

The authors declare no conflict of interest.

\section{Acknowledgements}

We would like to express our deepest appreciation to Research and Development from the Institute of research and community services, Universitas Diponegoro 2019 who provided us with the possibility to complete this study.

\section{References}

Ariyani, D.E., Achadi, E.L. and Irawati, A. (2012). Validity Mid-Upper Arm Curcumference to Detect Chronic Energy Malnutrition Risk of Indonesia Women. Jurnal Kesehatan Masyarakat Indonesia, 7 (2), 83-90. https://doi.org/10.21109/kesmas.v7i2.67

Golbidi, S., Daiber, A., Korac, B., Li, H., Essop, M.F. and Laher, I. (2017). Health benefits of fasting and caloric restriction. Current diabetes reports, 17, 123. https://doi.org/10.1007/s11892-017-0951-7

Gong, Q.H., Li, S.X., Li, H., Cui, J. and Xu, G.Z. (2018).
Insufficient Sleep Duration and Overweight/Obesity among Adolescents in a Chinese Population. International Journal of Environmental Research and Public Health, 15(5), 997. https:// doi.org/10.3390/ijerph15050997

Hadi, H., Ata, U.A. and Nurdiati, D. (2014). Tingkat Asupan Energi dan Ketersediaan Pangan berhubungan dengan Risiko Kekurangan Energi Kronik (KEK) pada Ibu Hamil. Jurnal Gizi Dan Dietetik Indonesia, 2(3), 140-149. [In Bahasa Indonesia]. https://doi.org/10.21927/ijnd.2014.2 (3). $140-149$

Hidayah, N., Zen Rahfiludin, M. and Aruben, R. (2016). Hubungan Status Gizi, Asupan Zat Gizi Dan Aktivitas Fisik Dengan Siklus Menstruasi Remaja Putri Pondok Pesantren Salafiyah Kauman Kabupaten Pemalang Tahun 2016. Jurnal Kesehatan Masyarakat, 4(4), 2356-3346. [In Bahasa Indonesia].

Holtzman, B. and Ackerman, K.E. (2019). Energy Intake in Athletes. Nutrients, 11(3), 1-13. https:// doi.org/10.3390/nu11030665

Inayati, P.C. (2009). Hubungan antara Status Gizi dan Menstruasi dengan Kejadian Anemia pada Santri Putri Pondok Pesantren Al-Hidayah Kecamatan Karang Rayung Kabupaten Grobogan Tahun 2009. Semarang, Indonesia: Universitas Negeri Semarang, BSc. Thesis. [In Bahasa Indonesia].

Jung, C.M., Melanson, E.L., Frydendall, E.J., Perreault, L., Eckel, R.H. and Right, K.P. (2011). Energy expenditure during sleep, sleep deprivation and sleep following sleep deprivation in adult humans. Journal of Physiology, 589(1), 235-244. https:// doi.org/10.1113/jphysiol.2010.197517

Kementrian Kesehatan RI. (2018). Hasil utama riskesdas 2018. Indonesia: Kementerian Kesehatan RI.

Khusniyati, E., Sari, A.K. and Ro'ifah, I. (2016). Hubungan Pola Konsumsi Makanan dengan Status Gizi Santri Pondok Pesantren Roudlatul Hidayah Desa Pakis Kecamatan Trowulan Kabupaten Mojokerto. Jurnal Kebiadanan, 2(2), 563.

Kustiyanti, D. and Kartasurya, M.I. (2017). Adakah Perbedaan Status Gizi antara Remaja Santriwati yang Berpuasa dan Tidak Berpuasa Senin Kamis? (Studi di Pondok Pesantren Al Itqon Semarang). Jurnal Kesehatan Masyarakat, 5(3), 129-137. [In Bahasa Indonesia].

Márquez, S. and Molinero, O. (2013). Energy availability, menstrual dysfunction and bone health in sports: an overview of the female athlete triad. Nutrition Hospitalaria, 28(4), 1010-1017.

Melin, A., Tornberg, Å.B., Skouby, S., Møller, S.S., 
Sundgot-Borgen, J., Faber, J., Sidelmann, J.J., Aziz, M. and Sjödin, A. (2015). Energy availability and the female athlete triad in elite endurance athletes. Scandinavian Journal of Medicine and Science in Sports, 25(5), 610-622. https://doi.org/10.1111/ sms. 12261

Mujiati, I., Budijanto, D. and Khairani. (2013). Situasi Keluarga Berencana di Indonesia. Indonesia: Kementrian Kesehatan Republik Indonesia.

Muliawati, S. (2013). Faktor Penyebab Ibu Hamil Kurang Energi Kronis di Puskesmas Sambi Kecamatan Sambi Kabupaten Boyolali Tahun 2012. Jurnal Imliah Rekam Medis Dan Informatika Kesehatan, 3(3), 40-62. [In Bahasa Indonesia].

Novziransyah, N. and Daulay, M.S. (2018). Hubungan Waktu Tidur dengan Kelebihan Berat Badan pada Mahasiswa dan Staf Pengajar FK UISU. Jurnal Komunitas Kedokteran Dan Tropik, 6, 265-270.

Ong, J.L. and Brownlee, I.A. (2017). Energy expenditure, availability, and dietary intake assessment in competitive female dragon boat athletes. Sports, 5(2), 45. https://doi.org/10.3390/ sports 5020045

Papageorgiou, M., Dolan, E., Elliott-Sale, K.J. and Sale, C. (2018). Reduced energy availability: implications for bone health in physically active populations. European Journal of Nutrition, 57(3), 847-859. https://doi.org/10.1007/s00394-017-1498-8

Ramadhaniah, Julia, M. and Huriyati, E. (2014). Durasi tidur, Asupan energi, dan Aktivitas Fisik dengan Kejadian obesitas pada Tenaga Kesehatan Puskesmas. Jurnal Gizi Klinik Indonesia, 11(2), 8596. https://doi.org/10.22146/ijcn.19011

Setyarsih, L., Ardiaria, M. and Fitranti, D.Y. (2017). Hubungan Densitas Energi dan Asupan Cairan dengan Berat Jenis Urin pada Remaja. Journal of Nutrition College, 6(4), 326-332. https:// doi.org/10.14710/jnc.v6i4.18670

Shechter, A., Rising, R., Albu, J.B. and St-Onge, M.P. (2013). Experimental sleep curtailment causes wakedependent increases in 24-h energy expenditure as measured by whole-room indirect calorimetry1-4. American Journal of Clinical Nutrition, 98(6), 14331439. https://doi.org/10.3945/ajen.113.069427

St-Onge, M.-P., Roberts, A.L., Chen, J., Kelleman, M., Keeffe, M.O., Roychoudhury, A. and Jones, P.J.H. (2011). Short Sleep Duration Increases Energy Intakes But Does Not Change Energy Expenditure in Normal-Weight Individuals. American Journal of Clinical Nutrition, 94(2), 410-416. https:// doi.org/10.3945/ajen.111.013904

Sygo, J., Coates, A.M., Sesbreno, E., Mountjoy, M.L. and Burr, J.F. (2018). Prevalence of indicators of low energy availability in elite female sprinters. International Journal of Sport Nutrition and Exercise Metabolism, 28(5), 490-496. https:// doi.org/10.1123/ijsnem.2017-0397

Taqhi, S.T.A., Dachlan, D.M. and Fatimah, S. (2014). Gambaran Sistem Penyelenggaraan Makanan di Pondok Pesantren Hubulo Gorontalo. Media Kesehatan Masyarakat Indonesia, 10(4), 241-247. http://dx.doi.org/10.30597/mkmi.v10i4.507

Westerterp, K.R. (2013). Physical activity and physical activity induced energy expenditure in humans: Measurement, determinants, and effects. Frontiers in Physiology, 4, 90. https://doi.org/10.3389/ fphys.2013.00090

Williams, N.I., Statuta, S.M. and Austin, A. (2018). Female Athlete Triad: Future Directions for Energy Availability and Eating Disorder Research and Practice. Clinical Sports Medicine, 36(4), 671-686. https://doi.org/10.1016/j.csm.2017.05.003 